\title{
Inter-annual ciliate distribution variation within the late stratification oxycline in a monomictic lake, Lake Alchichica (Mexico)
}

\author{
Ximena SÁNCHEZ MEDINA,,${ }^{1,2^{*}}$ Miroslav MACEK,,${ }^{2,3}$ Fernando BAUTISTA-REYES, ${ }^{2}$ Andrea PERZ, ${ }^{2}$ \\ Patricia BONILLA LEMUS, ${ }^{4}$ Mario CHÁVEZ ARTEAGA ${ }^{2}$
}

${ }^{1}$ Posgrado en Ciencias del Mar y Limnología, Universidad Nacional Autónoma de México, 54090 Tlalnepantla, México; ${ }^{2}$ Proyecto de Investigación en Limnología Tropical, Universidad Nacional Autónoma de México, 54090 Tlalnepantla, México; ${ }^{3}$ Biology Center, v.v.i., Academy of Sciences of the Czech Republic, České Budějovice, 37005 Czech Republic; ${ }^{4}$ Proyecto de Investigación en Conservación y Mejoramiento del Ambiente, FES Iztacala, Universidad Nacional Autónoma de México 54090 Tlalnepantla, México *Corresponding author: difttarz@hotmail.com

\begin{abstract}
Deep stratified tropical water bodies pass through prolonged periods of meta-hypolimnetic anoxia, and ciliates might play a very important role in the plankton community budget there. We analyzed changes in the composition and biomass of the ciliate assemblage and other microbial loop components throughout the oxycline just at the end of stratification in a warm-monomictic lake, Lake Alchichica, Mexico (four samplings: 2006-2008, 2010); the results were compared with those obtained from another lake from the region, La Preciosa, sampled in 2010. Bacteria, autotrophic picoplankton (APP) and flagellates were analyzed using epifluorescence microscopy. Ciliates were evaluated either in DAPI stained samples (looking for pigmented organelles and/or ingested phototrophs) or in quantitative protargol stain (QPS) permanent preparations, where they were identified at the genus or species level. The end of the stratification period in Lake Alchichica was characterized by almost uniform heterotrophic picoplankton (HPP) numbers (10 ${ }^{6}$ cells $\mathrm{mL}^{-1}$ ) throughout the water column. Meanwhile, APP showed epilimnetic and/or metalimnetic maxima of $10^{5}$ cells $m L^{-1}$ followed by an order of magnitude drop in the hypolimnion. A very important peak $\left(10^{5}\right.$ cells $\left.\mathrm{mL}^{-1}\right)$ of the autotrophic or mixotrophic flagellate Pyramimonas sp. was observed repeatedly above and within the oxycline of Lake Alchichica. Ciliate biomass maxima were found around the oxycline and in the above-bottom layer. The top of the oxycline was dominated by Euplotes spp. and Spirostomum teres fine- to coarse-filter feeders (feeding upon APP, nanodiatoms and algae). Raptorial haptorids (in particular, Phialina sp.) were the second most important group, generally occupying the layer below euplotids, followed by Holophrya and Prorodon facultative anaerobic prostomes. Sometimes, strictly anaerobic Caenomorpha sp. was found to be important in the anoxic hypolimnion. Minute picoplankton feeding species (both APP and heterotrophic bacteria feeders) were important throughout the water column: in the epilimnion, vorticellids (2006-2008) or scuticociliates (2010) dominated. Typically, the scuticociliate maximum was located in the oxycline and/or above the bottom. Some microaerophilic species were isolated; thus, their identification could be carried out. However, the apparent polymorphic ciliate life cycles were not described completely, and the species composition was only estimated: two dominant species (SC 1 - Cristigera-like and SC 2 - Cyclidim-like) covered nearly the total scuticociliate biomass. Strictly anaerobic scuticociliates were not isolated but observed in the deepest layers of the lake (bacteria symbiotic Isocyclidium globosum and Cristigera sp.). Significant statistical relation within the ciliate distribution and environmental variables was not confirmed due to unique species composition in the respective years. However, general trends in the distribution of ciliates on a species level were observed. Scuticociliates, including two important tentatively identified species, did not present unambiguous ecological position, and the study of their live cycle should be the next step in investigations.
\end{abstract}

Key words: Oxycline; ciliates; scuticociliates; mixotrophy; biomass.

Received: March 2015. Accepted: January 2016.

\section{INTRODUCTION}

The importance of ciliate biomass in stratified freshwater bodies has been quantified since the 1980s (Hecky and Kling, 1981; Beaver and Crisman, 1989; Müller et al., 1991; Sonntag et al., 2002; Pirlot et al., 2005; Macek et al., 2006; Yasindi et al., 2007), and their role in the microbial food web has been demonstrated, showing their feeding on bacteria (Sherr et al., 1991; Šimek et al., 1990, 1995; Weisse et al., 1990; Oikonomou et al., 2014), phytoplankton (Müller, 1989; Sommaruga and Psenner, 1993) and picocyanobacteria (Sherr et al., 1991; Šimek et al., 1995, Pernthaler et al., 1996; Peštová et al., 2008; Tarbe et al., 2011). Several studies have shown that during the annual cycle, ciliates typically present spring and summer peaks that are bottom-up- and top-down-controlled, respectively (Šimek el al., 1990, 1995; Weisse et al., 1990; Müller et al., 1991; Tirok and Gaedke, 2007; Sommer et al., 2012). However, plankton protists were not incorporated into the theoretical Plankton Ecology Group based model (PEG-based model) until 2012, reflecting their dif- 
ferent importance in oligotrophic versus eutrophic dimictic water bodies (Sommer et al., 2012). microbial food web structure and dynamics in tropical lakes, except for large African lakes (Tarbe et al., 2011; Sarmento, 2012), are only now being described (Macek et al., 2009; Sarmento, 2012).

Significant vertical gradients have been reported in both the diversity and abundance of ciliates, which are related to prey distribution and to physical and chemical variables, particularly to dissolved oxygen (Fenchel, 2012; Triadó-Margarit and Casamayor, 2015). Within the water column, ciliate abundance peaks often occur at phase boundaries such as the metalimnion, where food particles become trapped in the density gradient, or at the water/bottom interface, being tightly related to the dissolved oxygen (DO) gradient (Berninger et al., 1986; Fenchel et al., 1990; Guhl and Finlay, 1993; Bernard and Fenchel, 1996; Finlay et al., 1996; Guhl et al., 1996; Fenchel, 2012; Oikonomou et al., 2015). However, much information was obtained from permanently stratified meromictic lakes (Psenner and Schlott-Idl, 1985; Oikonomou et al., 2015, 2015) that might be different comparing to common stratified lakes. Penetration of photosynthetically active radiation (PAR) through a density gradient such as a thermocline or halocline (in meromictic lakes) is very important for picocyanobacteria-following feeders (Modenutti et al., 2002; Callieri, 2007; Peštová et al., 2008; Bautista-Reyes and Macek, 2012) and for zoochlorella and kleptoplasts or kleptochloroplasts-possessing mixotrophs either aerobic (Berninger et al., 1986; Modenutti and Balseiro, 2002; Woelfl and Geller, 2002) or those related to anoxic boundaries (Guhl and Finlay, 1993; Finlay et al., 1996; Finlay and Esteban, 1998; Oikonomou et al., 2015). Also, in the absence of dissolved oxygen, ciliates could be a very active component of the microbial food web (Wagener et al., 1990; Esteban et al., 1993a, b; Massana and Pedrós-Alió, 1994; Finlay et al., 1996; Fenchel, 2012; Bautista-Reyes and Macek, 2012).

Among the ciliates typical for the oxycline and/or oxic/anoxic boundaries, scuticociliates are very important, frequently possessing anaerobic metabolism coupled with the activity of prokaryote symbionts (Esteban et al., 1993a, 1993b; Bernard and Fenchel, 1996; Peštová et al., 2008; Bautista-Reyes and Macek, 2012). However, the taxonomy of the group is quite complicated due to their (in general) minute size (Foissner et al., 1999; last overview in Gao et al., 2014) and their potentially polymorphic life cycle (Pérez-Uz and Guinea, 2001).

Recently, morphology-based studies have been enriched with molecular biology, and greater anoxic protist richness has been reported, including many overlooked species (Oikomonou et al., 2015; Triadó-Margarit and Casamayor, 2015).

The information on ciliate stratification in tropical mo- nomictic water bodies is limited to a few such bodies (Hecky and Kling, 1981; Pirlot et al., 2005; Yasindi et al., 2007; Peštová et al., 2008; Tarbe et al., 2011; BautistaReyes and Macek, 2012; Mansano et al., 2013). Among them, Lake Alchichica investigations have included both general limnology and all trophic levels (cf., Macek et al., 2009; Oliva et al., 2001; Ciros-Pérez et al., 2015, for bacteria, phytoplankton and zooplankton / fish interactions, respectively). Subtropical lakes Biwa (Japan) and Kinneret (Israel) have also been well studied (Madoni, 1990; $\mathrm{Hu}$ and Kusuoka, 2015). All these lakes show highly important microbial food web processes (as defined in Sarmento, 2012) and might include anoxic/anaerobic ciliates as the driving force in their plankton dynamics.

The aim of this study was to analyze changes in the composition and biomass of the ciliate assemblage throughout the oxycline at the end of stratification in the warm-monomictic Lake Alchichica with a picocyanobacteria-rich metalimnion and an anoxic hypolimnion from the point of view of both ecology (microbial food web component distribution at the end of the lake's stratification of four years) and taxonomy, with special interest in scuticociliate morphospecies. The results are compared with the same period's ciliate assemblage in Lake La Preciosa.

\section{METHODS}

\section{Study area}

Maar-crater Lake Alchichica is at $19^{\circ} 24^{\prime} \mathrm{N}, 97^{\circ} 24^{\prime} \mathrm{W}$ and 2,340 $\mathrm{m}$ above sea level. The climate is dry and temperate with a mean annual temperature of $12.9^{\circ} \mathrm{C}$ and mean annual precipitation of less than $400 \mathrm{~mm}$ concentrated in the (summer) rainy season. It is a deep lake (maximum depth $62 \mathrm{~m}$, mean depth $40.9 \mathrm{~m}$ ) with a surface area of $2.3 \mathrm{~km}^{2}$ and a volume of $94,214,080 \mathrm{~m}^{3}$ (Filonov et al., 2006) of saline $\left(8.5 \mathrm{~g} \mathrm{~L}^{-1}\right)$ and alkaline $(\mathrm{pH} \mathrm{9.5)} \mathrm{water}$ (Armienta et al., 2008). It is a low-productive lake with an average annual chlorophyll $a$ concentration below 4 $\mu \mathrm{g} \mathrm{L}^{-1}$ (Macek et al., 2009).

The neighbouring lake La Preciosa $\left(19^{\circ} 22^{\prime} \mathrm{N}, 97^{\circ}\right.$ $23^{\prime} \mathrm{W}$ ) lies at an altitude of $2330 \mathrm{~m}$. It is a maar-crater produced by three phreatomagmatic explosions; the maximum depth found was $45 \mathrm{~m}$, but the water level is decreasing during recent years (drop approximately $3 \mathrm{~m}$ is being verified). It has alkaline water with a $\mathrm{pH}$ between 8.8 and 9 and $1.1 \mathrm{~g} \mathrm{~L}^{-1}$ salinity (Armienta et al., 2008).

\section{Sampling}

Samples have been taken in lake Alchichica on a monthly basis but in the article we present analyses of the samples from the end of the stratification period (November 2006, 2008 and 2010, and December 2007) taken from the deepest part of the lake between 10:00 a.m. and 12:00 p.m. Profiles of temperature, dissolved oxygen 
(DO) (Hydrolab DS4/SVR4 Water Quality Monitoring System) and photosynthetically active radiation (PAR) (LI-COR 1400) were analyzed to select discrete sampling depths. In the graphs, data profiles are presented from a day before and at the moment of sampling (Fig. 1). La Preciosa samples were taken in November 2010 (Fig. 2).

Biological samples were taken using a van Dorn-type sampler (IHE, Czech Republic). The samples for picoplankton and flagellate enumeration were fixed with formalin to 2\% (Straškrabová et al., 1999); meanwhile, the ciliate samples were fixed with concentrated Bouin`s fluid directly (picric acid saturated in formaline 5\%, acetic acid $2 \% \mathrm{v} / \mathrm{v}$ ) or Bouin's postfixed after acid Lugol (Montagnes and Lynn, 1993).

\section{Procedures}

Direct numbers of heterotrophic picoplankton (HPP) (bacterioplankton) were evaluated in samples concentrated onto polycarbonate membranes $(0.2 \mu \mathrm{m}$ pore-sized; Osmonics, Germany) that were DAPI-stained and mounted in immersion oil (Porter and Feig, 1980). Autotrophic picoplankton (APP) were evaluated on polycarbonate membranes $(0.2 \mu \mathrm{m})$ mounted in immersion oil via autofluorescence (Leica, Germany) using an Y3 filter set (Cy3; green excitation- and red observation-light).

To count ciliates, two methods were used in parallel: DAPI staining (samples cropped onto $2 \mu \mathrm{m}$ polycarbonate membranes; Osmonics, Germany) and quantitative protargol stain (QPS; modified following Montagnes and Lynn, 1987 and Skibbe, 1994 recommendations). Samples for QPS were filtered and agar-mounted onto membrane filters (1.2 $\mu \mathrm{m}$, Millipore, Ireland), and the agar was formalin fixed, stained, dehydrated (ethanol 70\%, 96\%, 96\%, phenol-xylene 2:3, xylene) and neutral Canada balsammounted. The whole filter area was inspected using $40 \times$ and 100× APO oil immersion objectives (Leica DMBH; Germany) equipped with Nomarski (DIC). Generally, the counting was repeated to obtain approximately $10 \%$ error in total numbers of ciliates, and the results were compared with DAPI counts.

For identification, Foissner et al. (1999) and literature cited therein were used. The QPS patterns of Alchichica ciliates have been registered routinely in recent years (Macek et al., 2006; Peštová et al., 2008; Bautista-Reyes and Macek, 2012), thus it was possible to confirm the identification of mixed-layer species by comparing them with the description of living samples sufficiently concentrated during the phytoplankton blooms (surface Nodularia sp. and deep chlorophyll maxima of Cyclotella alchichicana and Chaetoceros elmorei).

For scuticociliates, Gao et al. (2014) and cited literature were consulted. However, since there is no actual revision applicable for observed scuticociliates, valid species identification was not possible even though mor- phospecies were defined. Additionally, the QPS patterns of the samples were compared with those from scuticociliate cultures that were single-cell isolated in wheat-grain medium under microaerobic conditions using cultivation in a candle-jar (according to Trigg, 1985).

Volume biomass was calculated (using simple shape models) from dimensions measured in photographs taken of the protargol impregnated samples (Canon S-45 camera) using Image-Pro Express software (Media Cybernetics, Inc.) for cell measurement. To estimate organic carbon biomass, the conversion factor of $0.368 \mathrm{pg} \mathrm{C} \mu \mathrm{m}^{-3}$ (Jerome et al. 1993) was used.

\section{RESULTS}

\section{Lake Alchichica stratification of variables}

Lake Alchichica exhibited the seasonal pattern typical of deep warm monomictic water bodies with an anoxic hypolimnion (June to December) and overturn occurring at a temperature below $15^{\circ} \mathrm{C}$ beginning in late December (compare Macek et al., 2009). The chosen sampling dates showed a sharp oxycline even though the density stratification might not be stable (temperature gradient below $0.5^{\circ} \mathrm{C} \mathrm{m}^{-1}$ ); in the graph (Fig. $1 \mathrm{a}-\mathrm{d}$ ), two profiles taken within two days around the sampling are plotted. Except for 2007, the November samples were analyzed but the December samples were already partly mixed.

Photosynthetically active radiation (PAR) data revealed that the $1 \%$ PAR level was generally located above the oxycline, where 0.1 to $1 \%$ was registered. All samples but those from 2006 showed maximum APP numbers (up $1 \times 10^{5}$ cells $\mathrm{mL}^{-1}$ ) within the epilimnion with a drop in the metalimnion and a slight increase (local maximum peak) in the lower boundary of the metalimnion upon minimum DO (Fig. 1 e-h). However, the year 2006 presented low APP numbers throughout the epilimnion and an absolute maximum of $1.57 \times 10^{5}$ cells $\mathrm{mL}^{-1}$ just in the sharp oxycline (Fig. 1 a,e). Heterotrophic bacterioplankton did not show high variation within the water column (Fig. 1 e-h). All samplings but one presented numbers from 1 to $2.5 \times 10^{6}$ cells $\mathrm{mL}^{-1}$, with the local maximum in the oxycline being approximately $130 \%$ of the arithmetical mean bacteria number; the position coincided with that of maximum ciliate biomass. Below the metalimnion, numbers were dropping; in the very bottom, bacterial numbers were lower than in the water column.

Heterotrophic and mixotrophic nanoflagellates were not found to be numerically important in the water column showing 100 and 1000 cells L ${ }^{-1}$. However, in 2006 throughout the mixed layer, and again in 2010 in the oxycline, a minute green flagellate $(3.5 \times 5.5 \mu \mathrm{m}$, four flagella, and cup shaped chloroplast; cf., Pyramimonas sp.) reached $2.5 \times 10^{5}$ and $8.2 \times 10^{5}$ cells $\mathrm{mL}^{-1}$, respectively (Fig. $1 \mathrm{e}-\mathrm{h})$. Outside of that period, the flagellate was found in 


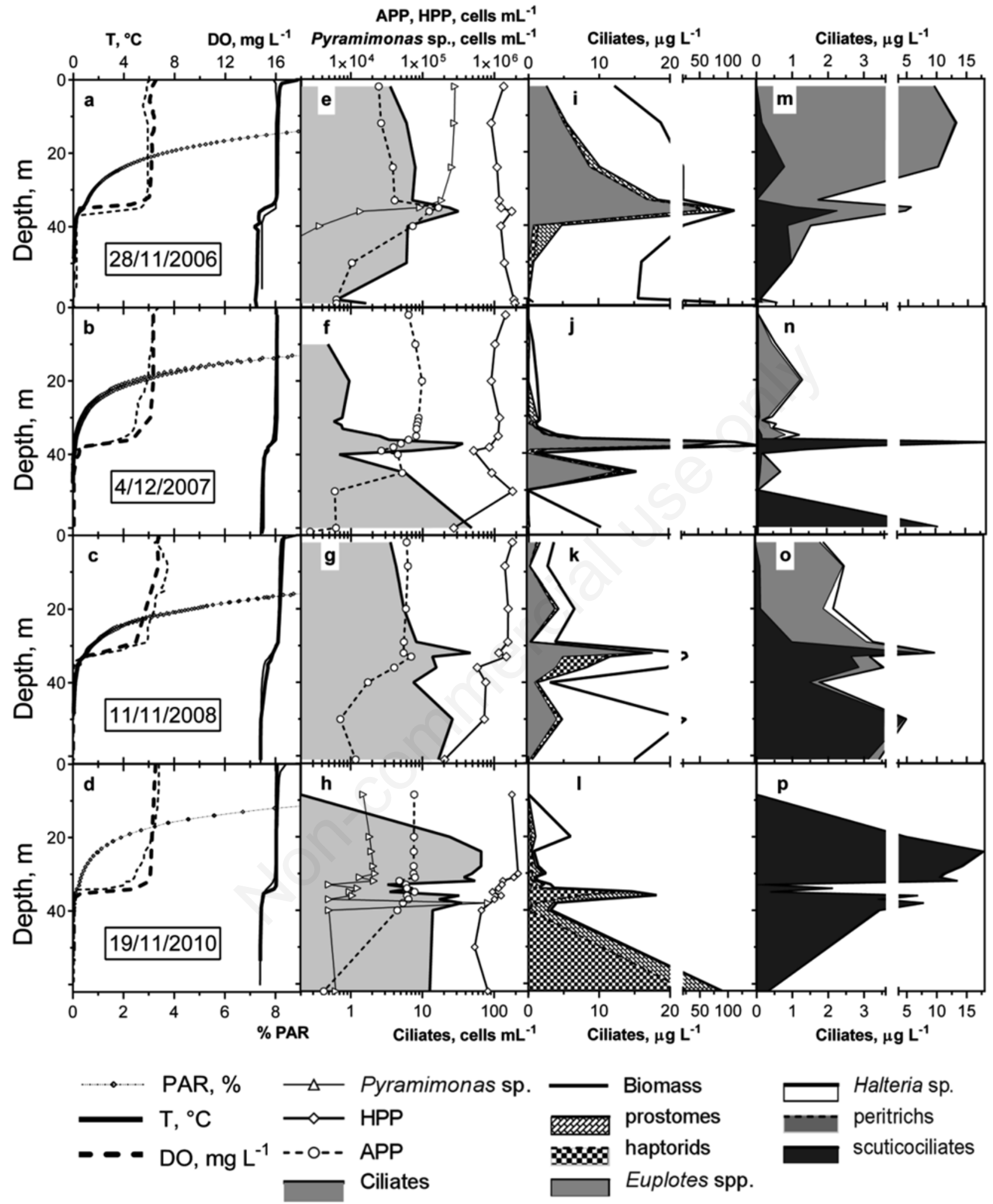

Fig. 1. Stratification of variables in Lake Alchichica. a-d) Dissolved oxygen (DO, $\left.\mathrm{mg} \mathrm{L}^{-1}\right)$, temperature $\left(\mathrm{T}\right.$, $\left.{ }^{\circ} \mathrm{C}\right)$ and photosynthetically active radiation (\% PAR); values from the sampling date are plotted in bold lines; thin lines represent the stratification \pm 2 days. e-h) Numbers (cells $\mathrm{mL}^{-1}$ ) of ciliates, autotrophic picoplankton (APP), heterotrophic picoplankton (HPP), and flagellates, Pyramimonas sp. $\mathrm{i}-1)$ Total ciliate organic carbon biomass $\left(\mu \mathrm{g} \mathrm{L}^{-1}\right)$ share of Euplotes spp., haptorids and prostomes. m-p) Cumulative biomass organic carbon $\left(\mu \mathrm{g} \mathrm{L}^{-1}\right)$ of scuticociliates, peritrichs and Halteria $\mathrm{sp}$. 
high numbers just during the start of the overturn in December 2008 (up $7.5 \times 10^{3}$ cells $\mathrm{mL}^{-1}$; data not shown).

\section{Ciliate distribution}

In total, 20 morphospecies were identified in Lake Alchichica: important ciliate maximum numbers and frequencies (=found in the sampling date) are pooled in Tab. 1 , and total ciliate numbers and ciliate biomass values are shown in Fig. 1 e-h and Fig. 1 i-m, respectively.

Frequently, the mixed layer was poor in ciliates, and peritrichs (Vorticella spp., Pelagovorticella natans) dominated the biomass, particularly in 2006 and 2008 (Figure $1 \mathrm{~m}-\mathrm{p}$ ). A local scuticociliate peak was found there in 2008 , but the absolute scuticociliate maximum was observed there in 2010 ( 22 cells mL $\mathrm{mL}^{-1}$ at 24 to $28 \mathrm{~m}$ ). Halteria cf. grandinella was observed throughout the mixed layers but was less abundant.

The total ciliate biomass was peaking in the metalimnion/oxycline, dominated by hypoxic and anoxic medium-sized and large ciliates (Fig.1 i-1). Euplotes spp. (apparently two species) presented an important layerspecific peak in the top of the oxycline (maximum of 34 cells $\mathrm{mL}^{-1}$ in 2007), but in 2010, they were nearly absent (they were found one month after during part mixing; data not shown). Haptorids (dominating: Phialina sp.; less biomass-important: Actinobolina sp., Belonophrya sp., Meso- dinium sp. and a minute Monodinium sp.) and prostomes (Prorodon sp. and/or Holophrya sp.) were concentrated within and below oxycline layers with undetectable DO or in the very bottom. In various samples, Spirostomum teres was observed in low numbers but, due to its very high individual cell biomass, it was very important (the error of the estimate could be high). Both euplotids and $S$. teres were observed with full vacuoles with APP along with the nanoplankton diatom Cyclotella choctawhatcheeana Prasad, 1990 and with green algae (other than Pyramimonas sp.).

The scuticociliate peak used to be found in the metalimnion/oxycline (6 to 100 cells $\mathrm{mL}^{-1}$ ) except for in 2010 when a significant drop was observed there (Fig. 1p) and the numbers reached high values again in the hypolimnion; additional above-bottom peaks were found in 2007 and 2008 (Fig.1 m-p).

In a detailed analysis of the composition of scuticociliates performed in the samples from 2007 and 2010, two dominant morphotypes were identified, apparently presenting sufficient differences to qualify them as species (Fig. 3). The morphotype SC1 was Cristigera-like, with a slightly visible longitudinal ventral groove, and some of the organisms presented clearly defined kineties on their anterior or posterior pole (Monteiro de Castro et al., 2014). The morphotype SC2 was Cyclidium-like with characteristics of the genus, e.g. a sole caudal cilium. In

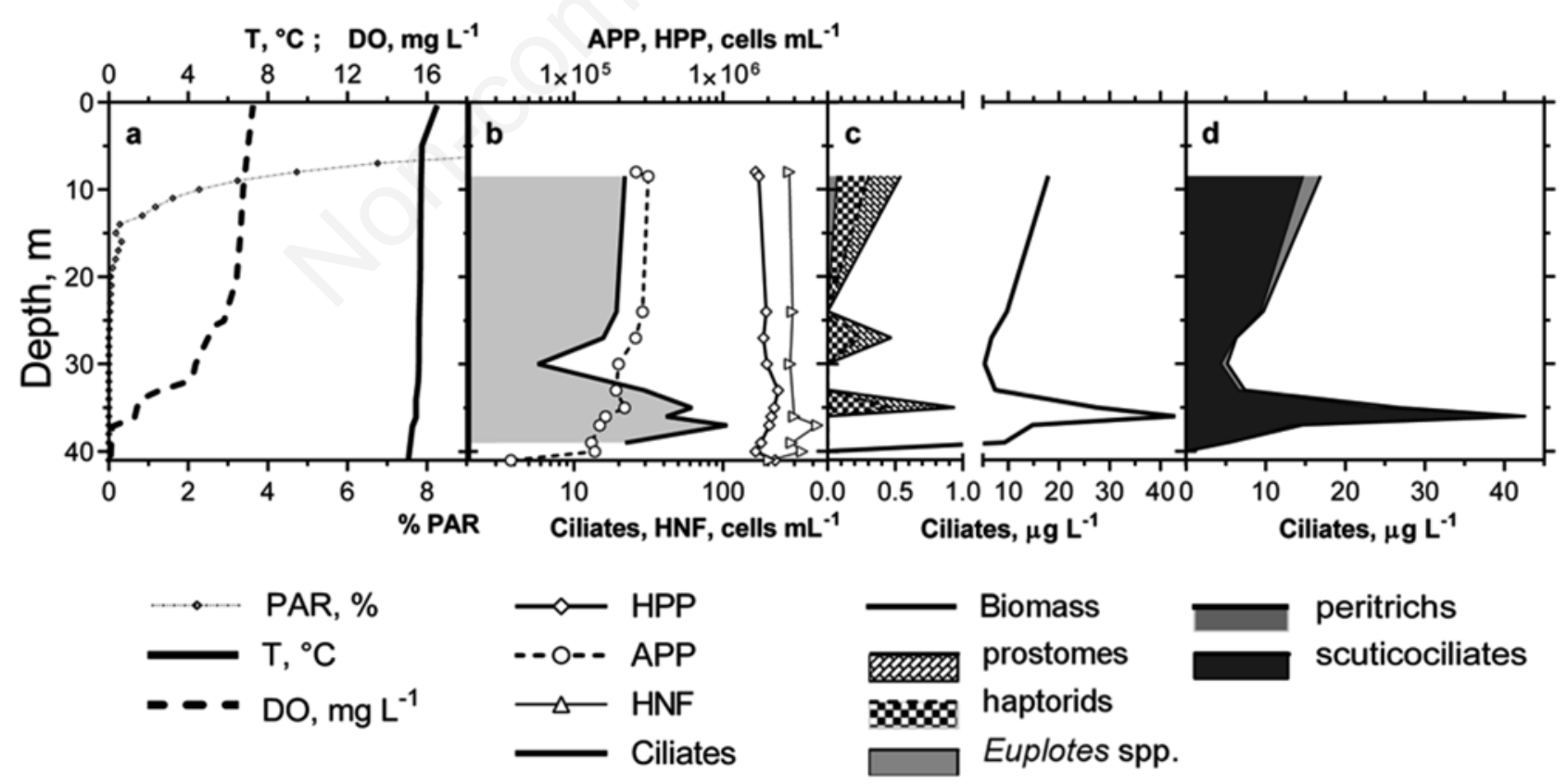

Fig. 2. Stratification of variables in Lake La Preciosa. a). Dissolved oxygen (DO, $\left.\mathrm{mg} \mathrm{L}^{-1}\right)$, temperature $\left(\mathrm{T}\right.$, $\left.{ }^{\circ} \mathrm{C}\right)$ and photosynthetically active radiation (\% PAR). b) Numbers (cells $\mathrm{mL}^{-1}$ ) of ciliates, autotrophic picoplankton (APP), heterotrophic picoplankton (HPP), and heterotrophic nanoflagellates (HNF). c) Total ciliate organic carbon biomass ( $\left.\mu \mathrm{g} \mathrm{L}^{-1}\right)$ share of Euplotes spp., haptorids and prostomes. d) Cumulative biomass organic carbon $\left(\mu \mathrm{g} \mathrm{L}{ }^{-1}\right)$ of scuticociliates and peritrichs. 
laboratory experiments both species were grown in a low oxygen concentration (candle-jar).

Isocyclidium globosum, which was registered in the lake in preceding years, was not found in significant numbers, and in the graphs it is grouped with other morphospecies such as Sathrophilus sp. (with an oral region on the center of the cell) or Uronema nigricans Müller, 1786. Other observed forms might be unidentified stages of other species or of those mentioned above, frequently with many nuclei and/or vacuoles.

In December 2007 (Fig. 3a), the biomass of ciliates was very low within the well-mixed layer, and scuticociliates were nearly absent. In the oxycline, a sharp absolute maximum of scuticociliates was observed, consisting almost solely of SC2. However, in the layer just below, scuticociliates were nearly absent. November 2010 did not follow the same pattern (Fig. 2b). SC2 was dominating with high biomass from $20 \mathrm{~m}$, peaking above the oxycline and again below the oxycline. However, just in the oxycline, ciliates were almost not observed (see above; Fig. 1p). In the deeper part of the hypolimnion, SC2 became more important but disappeared in the bottom.

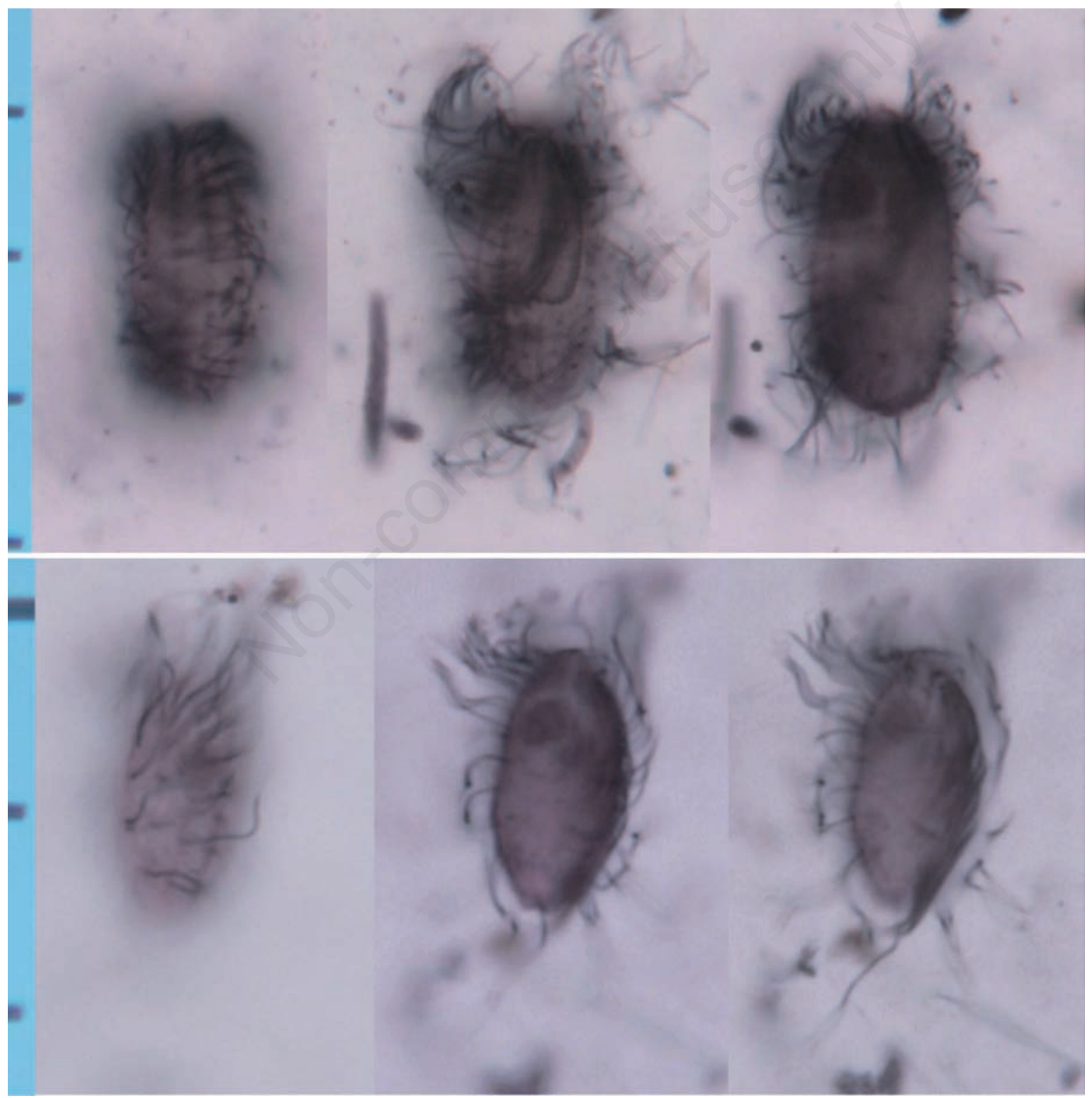

Fig. 3. Scuticociliate morphospecies SC1 - Cristigera-like (upper panel) and SC2 - Cyclidium-like (lower panel). Quantitative protargol impregnation. Scale bar: $10 \mu \mathrm{m}$. 
Within the scuticociliates that presented ingested APP, SC1 was found more frequently than SC2. However, a higher proportion of specimens with ingested APP was observed below the oxycline. Although APP were present in the very bottom, they were not ingested there.

Ciliates were abundant below the oxycline, showing an additional hypolimnetic maximum at $50 \mathrm{~m}$ or at the above bottom-layer (Figs. 1 and 4). In 2006, the bottom maximum was caused by $S$. teres, whereas in 2010 , Phialina sp. and Holophrya sp. dominated there. Sporadically, the strict anaerobe Caenomorpha sp. and odontostomatids were observed below the oxycline and in the very bottom.

\section{Lake La Preciosa}

Lake La Preciosa was sampled as a reference in the same 2010 campaign as Alchichica. Because of the smaller size of the crater and its open shape facilitating wind blowing, the lake was already being mixed, but an oxycline was still present (Fig. 2a). According to its APP distribution (Fig. 2b), intense mixing took place down to $24 \mathrm{~m}$ (over $2.5 \times 10^{5}$ cells $\mathrm{mL}^{-1}$ ); DO was decreasing gradually below this layer, reaching anoxia at $37 \mathrm{~m}$. The lake was slightly turbid, and $1 \%$ and $0.1 \%$ PAR were found at 12 and $19 \mathrm{~m}$, respectively. A local maximum of APP $\left(2.19 \times 10^{5}\right.$ cells $\left.\mathrm{mL}^{-1}\right)$ was observed above the oxycline $(35 \mathrm{~m})$. Heterotrophic nanoflagellates (HNF) were found in quite low numbers (Fig. 2b).

In total, 11 ciliate taxa were identified (Tab. 1), two- fold fewer than in Alchichica. The only taxon not found in Alchichica was the haptorid Lacrymaria sp. Also in this lake, ciliate biomass decreased through the well-mixed layer (Fig. 2 b-d), and a steep maximum was found at the oxycline with scuticociliates absolutely dominating; anoxic ciliates were negligible.

La Preciosa presented the highest biomass and proportion of scuticociliates within the assemblage (Fig. 4c). The whole column was dominated by SC2, peaking just above the oxycline. Scuticociliates were found with ingested APP.

\section{DISCUSSION}

Ciliate samples taken at roughly the same stage of Lake Alchichica's annual stratification cycle and in Lake La Preciosa showed quite similar patterns from the point of view of the distribution of biomass among the main ecological groups (as defined in Macek et al., 2006), but differences were found at the species level. The most important ciliates throughout the mixed layer were related to picoplanctivory on both APP and heterotrophic bacteria. In the epilimnion, the dominant groups were the vorticellids (both free-living Pelagovorticella natans and other diatom-attached vorticellids); Halteria cf. grandinella did not present as much biomass. As usual for Mexican Plateau saline lakes, almost no oligotrichs or choreotrichs were observed (compare Macek et al., 1994, 2006; Peštová et al., 2008). Bacterivorous/omnivorous scuticociliates were found to be dominating in both

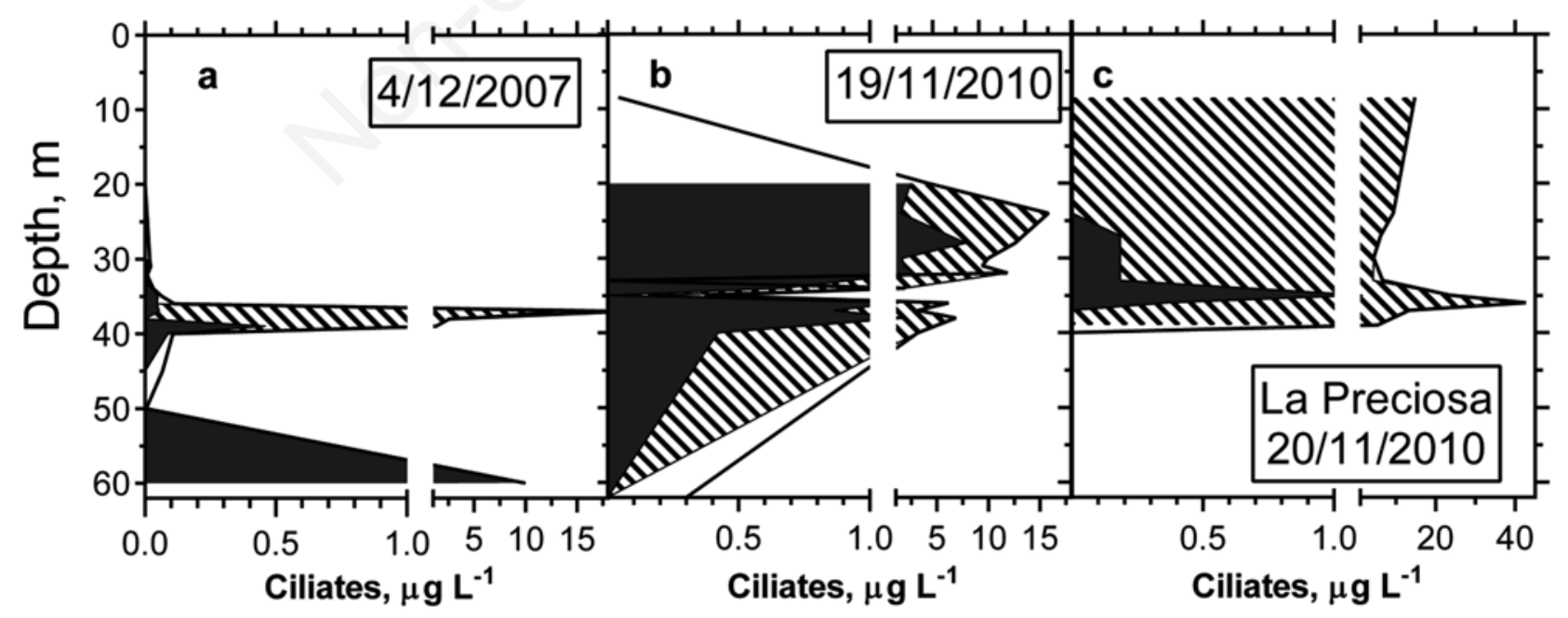

$\square$ SC 1 XV SC 2 - scuticociliates

Fig. 4. Distribution of scuticociliate morphospecies SC1 (Cristigera-like) and SC2 (Cyclidium-like) in Alchichica (a,b) and La Preciosa (c) lakes. 
Alchichica and La Preciosa only in 2010 when they were possibly driven from the deteriorated oxycline (compare Šimek et al., 1995). Within the mixed layer, nanophytoplankton-feeding ciliates were reduced to Euplotes spp. (almost absent in La Preciosa), which are not common freshwater pelagic ciliates. Other algivorous ciliates were represented by large Holophrya and Prorodon species but rarely outside the anoxic hypolimnion; typical minute hunting prostomes such as Balanion planctonicum and Urotricha sp. were absent (compare Müller, 1989; Šimek et al., 1995; Sonntag et al., 2002 vs Macek et al., 2006).

A well pronounced oxycline leading to anoxia was apparently a limit of former hypolimnion although the thermocline was already in the process of deterioration on the sampling date (Fig. 1 a-d); dissolved oxygen minimum was supported by the heterotrophic activity of organisms in the layer. However, the physical phase boundary was not a barrier to ciliate migration. Scuticociliates showed maximum peaks in the oxycline top but penetrated through the anoxic hypolimnion. There is no doubt the scuticociliates were searching for their prey bacteria within the anoxic layers even though they are not necessarily anaerobic (compare Fenchel et al., 1990; Esteban et al., 1993a, 1993b; Bernard and Fenchel, 1996; BautistaReyes and Macek, 2012). In laboratory experiments it was proved that typically observed morphospecies could be single-cell-isolated and grown in a low oxygen concentration (5\% according to Trigg, 1985); however, scuticociliates observed in situ covered with symbiotic bacteria (Isocyclidium globosum in Peštová et al., 2008; Cristigera-like ciliate in Bautista-Reyes and Macek, 2012) were not isolated. Observations in the single cell-origin cultures also revealed the fact that the present scuticociliates possess a polymorphic life cycle (Pérez-Uz and Guinea, 2001), which explains problems with the taxonomical analysis of the samples.

Predatory haptorids (Actinobolina sp. and Belonophrya sp.) followed other ciliates to the anoxic layers;

Tab. 1. Identified taxa of ciliates in lakes Alchichica and La Preciosa: Absolute one layer maximum abundance and positive samplingdate frequency (La Preciosa was sampled one time).

\begin{tabular}{|c|c|c|c|}
\hline Identified ciliates & $\begin{array}{l}\text { Alchichica } \\
\text { Maximum } \\
\text { cells } \mathrm{mL}^{-1}\end{array}$ & $\begin{array}{l}\text { Frequency } \\
\text { (data) }\end{array}$ & $\begin{array}{l}\text { La Preciosa } \\
\text { Maximum } \\
\text { cells } \mathrm{mL}^{-1}\end{array}$ \\
\hline $\begin{array}{l}\text { Heterotrichea Stein, } 1859 \\
\quad \text { Spirostomum teres Claparède \& Lachmann, } 1859\end{array}$ & 0.69 & 3 & - \\
\hline $\begin{array}{l}\text { Stichotrichia Small \& Lynn, } 1985 \\
\text { Euplotes Ehrenberg in Hemprich \& Ehrenberg, } 1831 \\
\text { Halteria grandinella (Müller, 1773) } \\
\text { Uroleptus rattulus Stein, } 1859\end{array}$ & $\begin{array}{l}33.6 \\
0.95 \\
0.05\end{array}$ & $\begin{array}{l}4 \\
4 \\
4\end{array}$ & $\begin{array}{c}0.03 \\
0.05 \\
-\end{array}$ \\
\hline $\begin{array}{l}\text { Haptoria Corliss, } 1974 \\
\text { Actinobolina } \text { Strand, } 1928 \\
\text { Belonophrya André, } 1914 \\
\text { Monodinium Fabre-Domergue, } 1888 \\
\text { Lacrymaria } \text { Bory de St. Vincent, } 1824 \\
\text { Litonotus } \text { Wrzesniowski, } 1870 \\
\text { Phialina } \text { Bory de St. Vicent, } 1824\end{array}$ & $\begin{array}{l}1.59 \\
1.78 \\
0.21 \\
- \\
0.16 \\
4.19\end{array}$ & $\begin{array}{l}4 \\
2 \\
4 \\
0 \\
3 \\
4\end{array}$ & $\begin{array}{c}- \\
- \\
- \\
0.1 \\
0.03 \\
0.11\end{array}$ \\
\hline $\begin{array}{l}\text { Armophorea Lynn, } 2004 \\
\text { Caenomorpha Perty, } 1852\end{array}$ & 1.48 & 4 & - \\
\hline $\begin{array}{l}\text { Litostomatea Small \& Lynn, } 1981 \\
\text { Mesodinium Stein, } 1863\end{array}$ & 0.42 & 3 & - \\
\hline $\begin{array}{l}\text { Peritrichia Stein, } 1859 \\
\text { Astylozoon Engelmann, } 1862 \\
\text { Pelagovorticella natans Jankowski, } 1985 \\
\text { Vorticella aquadulcis-complex } \\
\text { Vorticella Linnaeus, } 1767\end{array}$ & $\begin{array}{l}0.03 \\
3.23 \\
0.80 \\
3.13\end{array}$ & $\begin{array}{l}1 \\
3 \\
1 \\
4\end{array}$ & $\begin{array}{c}- \\
0.80 \\
- \\
0.24\end{array}$ \\
\hline $\begin{array}{l}\text { Scuticociliatia Small, } 1967 \\
\text { Isocyclidium globosum Esteban, Finlay \& Embley, } 1993 \\
\text { Sathrophilus Corliss, } 1960 \\
\text { SC1 (Cristigera-like) } \\
\text { SC2 (Cyclidium-like) } \\
\text { Scuticociliatia g. spp. }\end{array}$ & $\begin{array}{l}20.3 \\
0.37 \\
>50 \\
\sim 100 \\
\sim 50\end{array}$ & $\begin{array}{l}3 \\
3 \\
4 \\
4 \\
4\end{array}$ & $\begin{array}{c}- \\
- \\
8.28 \\
100 \\
2.00\end{array}$ \\
\hline $\begin{array}{l}\text { Prostomatea Schewiakoff, } 1896 \\
\text { Holophrya } \text { Ehrenberg, } 1831 \\
\text { Prorodon Ehrenberg, } 1834\end{array}$ & $\begin{array}{l}6.78 \\
6.36\end{array}$ & $\begin{array}{l}3 \\
1\end{array}$ & $\begin{array}{c}0.05 \\
-\end{array}$ \\
\hline
\end{tabular}


Prorodon sp. prostomes and even more typically Holophrya sp. were found in the very bottom (including in Lake La Preciosa). Curiously, a similar ciliate composition (including Cristigera sp., Euplotes sp. and Holophrya sp.) was found in African shallow soda lakes (Ong'ondo et al., 2013); however, these lakes were continuously mixing. Phialina $\mathrm{sp}$. frequently dominate the oxycline ciliate biomass (Macek et al., 2006; Peštová et al., 2008; Bautista-Reyes and Macek, 2012), although this finding has not been supported with data from similarly stratified lakes. Even in Lake Kinneret showing similar oxycline behavior, the genus Phialina was not found in plankton from the water/sediment interface (Madoni, 1990). On the other hand, according to findings in smaller but stratified water bodies, water/sediment boundary ciliates would migrate to the pelagic layers (Berninger et al., 1986; Esteban et al., 1993a, 1993b; Guhl et al., 1996;
Oikonomou et al., 2014, 2015). In our study we found that, if such events occurred, the ciliates migrated to a very thin layer with specific environmental conditions presenting a patchy distribution.

There is a serious problem with sampling of the oxycline in Alchichica: internal waves of the thermocline/oxycline with quite a short period of approximately $20 \mathrm{~min}$ (Filonov et al., 2006) are sufficient to disrupt fine sampling. This may explain why the ciliate and other microorganism components of the microbial food web varied in the samples without any apparent relation within the years, and why traditional statistical analytical tests did not show significant correlations except that of temperature (stratification) and co-correlations between limnological variables. Instead, a quasi three-dimensional plot of ciliate abundance against DO and PAR is shown (Fig. 5).

In the graph, it can see that, according to the course of

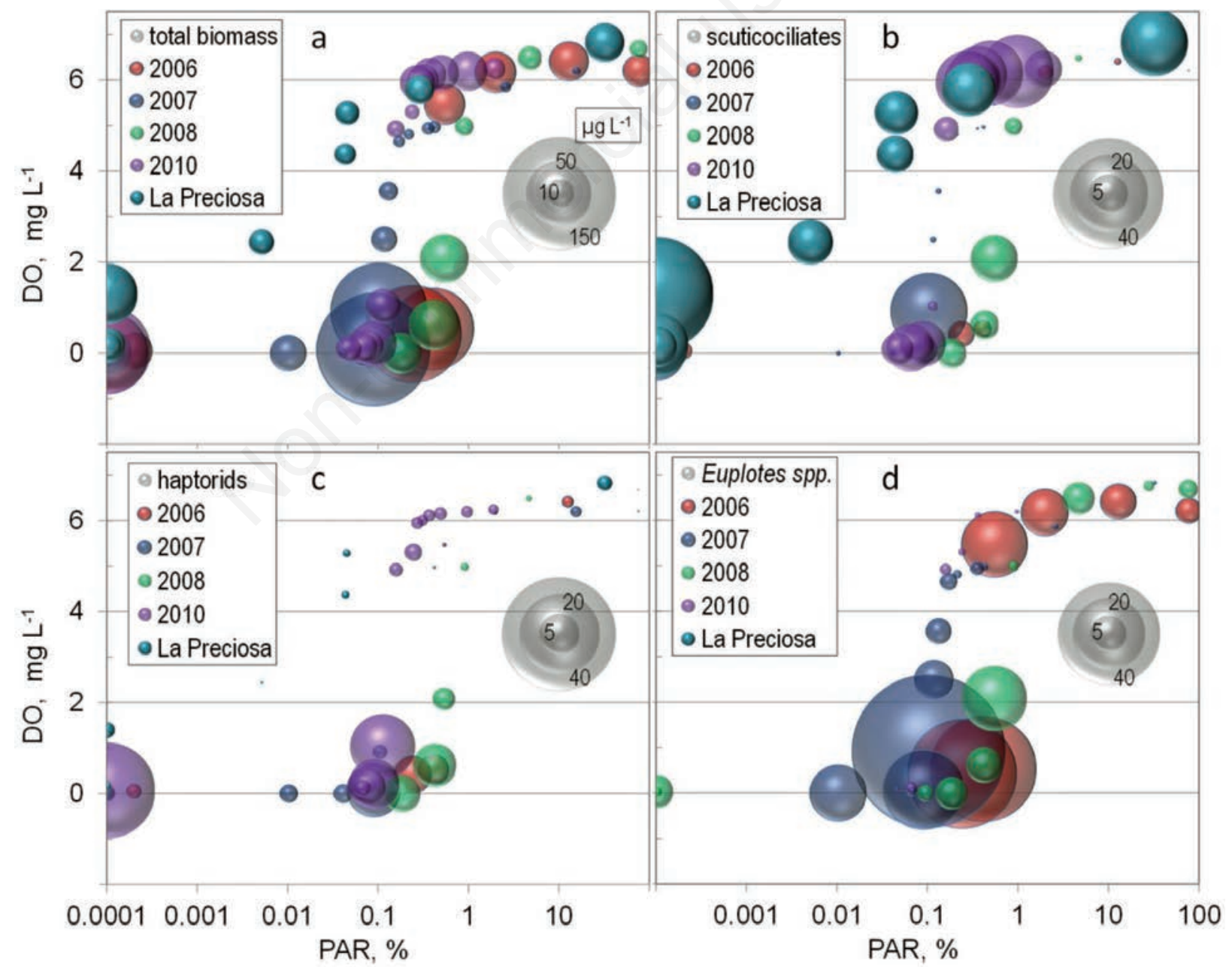

Fig. 5. Ciliate organic carbon biomass $\left(\mu g \mathrm{~L}^{-1}\right)$ plotted against dissolved oxygen $\left(\mathrm{DO}, \mathrm{mg} \mathrm{L}^{-1}\right)$ and photosynthetically active radiation (\% PAR). Concentric circles (right) show referential ciliate biomass. 
the biomass plot, PAR and DO were not independent variables in Lake Alchichica. DO disappeared at the PAR level of approximately $0.1 \%$, exactly were the highest $E u$ plotes spp. biomass was observed (Fig. 5a). Haptorids (Fig. 5c) peaked just below the oxycline; Phialina sp. dominating there showed the highest biomass in complete darkness and without oxygen (low numbers were observed there). The total ciliate biomass showed important values in DO of approximately $6 \mathrm{mg} \mathrm{L}^{-1}$ (Fig. 5a) reflecting the occurrence of peritrichs and/or scuticociliates (Fig. 5 b), which dominated there only in 2010. Scuticociliates showed an additional cluster of important biomass in negligible DO, but generally, the group showed very diverse behavior.

It has been documented that mixotrophic species can dominate the oxycline and even move it down due to their photosynthetic activity (mixotrophic Acaryophrya sp. and others in Berninger et al., 1986; Prorodon sp. in Finlay et al., 1996; complex assemblage in Finlay and Esteban, 1998; Ophrydium naumanni in Modenutti and Balseiro, 2002; Stentor spp. in Woelfl and Geller, 2002), but in Lake Alchichica, even though potentially symbiotic Holophrya sp. was found, the oxycline was located below the layer efficient for oxygenic photosynthesis (even below $0.5 \%$ PAR; Fig. 1 a-d). Moreover, many of the above-mentioned mixotrophs are known as raptorial feeders on dinoflagellates (Finlay and Esteban, 1998), which (and similar potential prey for protists) are absent from Alchichica. Euplotes spp. feeding on APP were found in the plankton of both lakes, and they were spectacularly dominating above the oxycline in 2007 (but they were scarce in the analyzed samples from La Preciosa). According to morphological observations, two similar species (one without ingested algae and observed throughout the mixed layer) were present simultaneously. Symbiosis has been hypothesized for euplotids (Peštová et al., 2008; Bautista Reyes and Macek, 2012) because of the notorious presence of large bright chlorophyll $a$ containing cells contrasting with vacuoles filled with APP, but it has not been proved. Compared to the zoochlorella-symbiotic E. daidaleos (Finlay and Esteban, 1998), our euplotids possessed only a small amount of algae.

Spirostomum teres was also found feeding on APP and nanoplankton but potentially anoxygenic-photosynthetic bacteria, abundant below the oxycline in lake La Preciosa, were not found being ingested (no infrared fluorescence typical for bacteriochlorophylls was observed). Loxodes spp., which might be related to such bacterial symbionts (Guhl and Finlay, 1993), were never observed, probably because of the lake's salinity. However, Phialina sp. was observed with bacteria inside many vacuoles as identified by CARD FISH applying a sulphate-reducing bacteria (SBR) probe (Bautista-Reyes and Macek, 2012; presented as Gymnostomatid ciliate). Although the probe is not di- rectly specific (it hybridizes with Deltaproteobacteria, containing many sulphate-reducing members), some symbiosis is possible. The same Phialina sp. was observed with picocyanobacteria on another occasion.

Strictly anaerobic ciliates except for Caenomorpha sp. and Isocyclidium globosum were not found to be abundant (compare Wagener et al., 1990; Massana and Pedrós-Alió, 1994; Guhl et al., 1996; Oikonomou et al., 2015). Due to high sulphate content (Armienta et al., 2008), the redox potential of the lakes likely did not reach the necessary level for their development.

From the results, it is evident (Figure 5) that ciliates in the lakes formed two typical clusters, within and below the oxycline and in the surface/mixed layer, which were spatially separated. The most evident case was the year 2010, when almost no ciliates were found in the oxycline but local ciliate maximums were found above and below it. Such critical depths characterized by both DO and PAR stratification could reflect elimination by, and/or an escaping mechanism from, their copepod predators; meanwhile it was shown that the copepods were escaping from fish (Ciros Perez et al., 2015).

\section{CONCLUSIONS}

The end of the stratification period in Lake Alchichica was characterized by almost uniform HPP numbers $\left(10^{6}\right.$ cells $\mathrm{mL}^{-1}$ ) throughout the water column, while APP showed epilimnetic and/or metalimnetic maxima of $10^{5}$ cells $\mathrm{mL}^{-1}$, followed by an order of magnitude drop in the hypolimnion. A very important peak $\left(10^{5}\right.$ cells $\left.\mathrm{mL}^{-1}\right)$ of the green flagellate Pyramimonas sp. was observed repeatedly above and within the oxycline of Lake Alchichica.

Detailed ciliate analysis of Lake Alchichica's late stratification revealed a similar general pattern of total biomass distribution throughout the water column with typical maxima above and below the oxycline, apparently separated. However, from the point of view of the biomass of different ciliate ecological groups, the composition and fine distribution of ciliates varied substantially from year to year. The mixed layer was dominated by omnivorous picoplanktonfeeding ciliates (feeding on APP was recorded), in particular, by vorticellids, and, when the stratification had just started to deteriorate, by scuticociliates.

The oxycline top was dominated by fine- to coarsefilter feeders, Euplotes spp. and Spirostomum teres (feeding on APP, nanodiatoms and algae). Raptorial haptorids (in particular, Phialina sp.) were the second most important group, generally occupying the layer below euplotids and followed by the facultative anaerobic prostomes Holophrya and Prorodon. Sometimes, anaerobic fine-filter feeders (bacterivorous scuticociliates) and anaerobic Caenomorpha sp. were found abundantly in the anoxic hypolimnion. 
Significant statistical relations involving the ciliate distribution and environmental variables were not confirmed owing to the unique species composition in the respective years. However, general trends in the distribution on the species level were observed, confirming the specificity of their optimal environment. Scuticociliates did not present unambiguous behavior as a group, and the study of their life cycle on the species level should be the next step in investigations.

\section{ACKNOWLEDGMENTS}

Ximena Sánchez Medina's Master studies were supported by a CONACYT scholarship. M. Macek's research was supported by grant UNAM DGPA/PAPIIT IN208502 and CONACYT Mexico - DLR Germany bilateral grant 1203801, with which Andrea Perz finished her B.S. thesis. Patricia Bonilla Lemus and Mario Chávez Arteaga were supported by an internal FES UNAM grant PAPCA 2009. We greatly appreciate Javier Alcocer for physico-chemical profiles, Luis Oseguera-Pérez for technical support in the field and Blanca Pérez-Uz for help with the identification of scuticociliates. English certificate was issued by Nature Publishing Group Language Editing.

\section{REFERENCES}

Armienta MA, Vilaclara G, De la Cruz-Reyna S, Ramos S, Ceniceros N, Cruz O, Aguayo A, Arcega-Cabrera F, 2008. Water chemistry of lakes related to active and inactive Mexican volcanoes. J. Volcanol. Geotherm. Res. 178:249-258.

Bautista-Reyes F, Macek M, 2012. Ciliate food vacuole content and bacterial community composition in the warm-monomictic crater lake Alchichica (México). FEMS Microbiol. Ecol. 79:85-97.

Beaver JR, Crisman TL, 1989. The role of ciliated protozoa in pelagic freshwater ecosystems. Microb. Ecol. 17:111-136.

Bernard C, Fenchel T, 1996. Some microaerobic ciliates are facultative anaerobes. Eur. J. Protistol. 32:293-297.

Berninger UG, Finlay BJ, Canter HM, 1986. The spatial distribution and ecology of zoochlorellae-bearing ciliates in a productive pond. J. Protozool. 33:557-563.

Callieri C, 2007. Picophytoplankton in freshwater ecosystems: the importance of small-sized phototrophs. Freshwater Rev. $1: 1-28$.

Ciros-Pérez J, Ortega-Mayagoitia E, Alcocer J, 2015. The role of ecophysiological and behavioral traits in structuring the zooplankton assemblage in a deep, oligotrophic, tropical lake Limnol. Oceanogr. 60: 2158-2172.

Esteban G, Finlay BJ, Embley TM, 1993a. New species double the diversity of anaerobic ciliates in a Spanish lake. FEMS Microbiol. Lett. 109:93-100.

Esteban G, Guhl BE, Clarke KJ, Embley TM, Finlay BJ, 1993 b. Cyclidium porcatum n. sp.: a free-living anaerobic scuticociliate containing a stable complex of hydrogenosomes, Eubacteria and Archeobacteria. Eur. J. Protistol. 29:262-270.

Fenchel T, 2012. Protozoa and oxygen. Acta Protozool. 52:11-20.

Fenchel T, Kristensen LD, Rasmussen L, 1990. Water column anoxia: vertical zonation of planktonic protozoa. Mar. Ecol. Prog. Ser. 62:1-10.

Filonov A, Tereshchenko I, Alcocer J, 2006. Dynamic response to mountain breeze circulation in Alchichica, a crater lake in Mexico. Geophysic. Res. Lett. 33:L07404.

Finlay BJ, Esteban GF, 1998. Planktonic ciliate species diversity as an integral component of ecosystem function in a freshwater pond. Protist 149:155-165.

Finlay BJ, Maberly SC, Esteban GF, 1996. Spectacular abundance of ciliates in anoxic pond water: Contribution of symbiont photosynthesis to host respiratory oxygen requirements. FEMS Microbiol. Ecol. 20:229-235.

Foissner W, Berger H, Schaumburg J, 1999. Identification and ecology of limnetic plankton ciliates. Informationsberichte des Bayer. Landesamtes für Wasserwirtschaft 3/99.

Gao F, Gao S, Wang P, Katz LA, Song W, 2014. Phylogenetic analyses of cyclidiids (Protista, Ciliophora, Scuticociliatia) based on multiple genes suggest their close relationship with thigmotrichids. Mol. Phylogenet. Evol. 7:219-226.

Guhl BE, Finlay BJ, 1993. Anaerobic predatory ciliates track seasonal migrations of planktonic photosynthetic bacteria. FEMS Microbiol. Lett. 107:313-316.

Guhl BE, Finlay BJ, Schink B, 1996. Comparison of ciliate communities in the anoxic hypolimnia of three lakes: general features and the influence of lake characteristics. J. Plankton Res. 18:335-353.

Hecky RE, Kling HJ, 1981. The phytoplankton and protozooplankton of the euphotic zone of Lake Tanganyika: species composition, biomass, chlorophyll content and spatio-temporal distribution. Limnol. Oceanogr. 26:548-564.

$\mathrm{Hu}$ X, Kusuoka Y, 2015. Two oxytrichids from the ancient Lake Biwa, Japan, with notes on morphogenesis of Notohymena australis (Ciliophora, Sporadotrichida). Acta Protozool. 54:107-122.

Jerome CA, Montagnes DJS, Taylor FJR, 1993. The effect of the quantitative protargol stain and Lugol's and Bouin's fixatives on cell size: a more accurate estimate of ciliate species biomass. J. Eukaryot. Microbiol. 40:254-259.

Macek M, Alcocer J, Lugo-Vázquez A, Martínez-Pérez ME, Peralta-Soriano L, Vilaclara-Fatjó G, 2009. Long term picoplankton dynamics in a warm-monomictic, tropical high altitude lake. J. Limnol. 68:183-192.

Macek M, Callieri C, Šimek K, Lugo-V A, 2006. Seasonal dynamics, composition and feeding patterns of ciliate assemblages in oligotrophic lakes covering a wide $\mathrm{pH}$ range. Arch. Hydrobiol. 166:261-287.

Macek M, Vilaclara G, Lugo A, 1994. Changes in protozoan assemblage structure and activity in a stratified tropical lake. Mar. Microb. Food Webs 8:235-249.

Madoni P, 1990. The ciliated protozoa of the monomictic Lake Kinneret (Israel): species composition and distribution during stratification. Hydrobiologia 190:111-120.

Mansano AS, Hisatugo KF, Leite MA, Luzia AP, Regali-Seleghim MH, 2013. Seasonal variation of the protozooplanktonic community in a tropical oligotrophic environment (Ilha Solteira reservoir, Brazil). Braz. J. Biol. 73:321-330.

Massana R, Pedrós-Alió C, 1994. Role of anaerobic ciliates in planktonic food webs: abundance, feeding, and impact on bacteria in the field. Appl. Environ. Microbiol. 60:1325-1334.

Modenutti BE, Balseiro EG, Quemaliños CP. 2002. Mixotrophic 
ciliates in an Andean lake: dependence on light and prey of an Ophrydium naumanni population. Freshwater Biol. 47:121-128.

Montagnes DJS, Lynn DH, 1987. A quantitative protargol stain (QPS) for ciliates: method description and test of its quantitative nature. Mar. Microb. Food Webs 2:83-93.

Monteiro de Castro LA, Küppers GC, Schweikert M, Harada ML, da Silva Paiva T, 2014. Ciliates from eutrophized water in the northern Brazil and morphology of Cristigera hammeri Wilbert, 1986 (Ciliophora, Scuticociliatia). Eur. J. Protistol. 50:122-133.

Müller H, 1989. The relative importance of different ciliate taxa in the pelagic food web of Lake Constance. Microb. Ecol. 18:261-274.

Müller H, Schöne A, Pinto-Coelho RM, Schweizer A, Weisse T, 1991. Seasonal succession of ciliates in Lake Constance. Microb. Ecol. 21:119-138.

Oliva MG, Lugo A, Alcocer J, Peralta L, Sánchez Ma del R, 2001. Phytoplankton dynamics in a deep, tropical, hyposaline lake. Hydrobiologia 466:299-306.

Oikonomou A, Filker S, Breiner HW, Stoeck T, 2015. Protistan diversity in a permanently stratified meromictic lake (Lake Alatsee, SW Germany). Environ. Microbiol. 17:2144-2157.

Oikonomou A, Pachiadaki M, Stoeck T, 2014. Protistan grazing in a meromictic freshwater lake with anoxic bottom water. FEMS Microbiol. Ecol. 87:691-703.

Ong' ondo GO, Yasindi AW, Oduor SO, Jost S, Schagerl M, Sonntag B, Boenigk J, 2013. Ecology and community structure of ciliated protists in two alkaline-saline Rift Valley lakes in Kenya with special emphasis on Frontonia. J Plankton Res. 35:759-771.

Pérez-Uz B, Guinea A, 2001. Morphology and infraciliature of a marine scuticociliate with a polymorphic life cycle: Urocryptum tortum n. gen., n. comb. J. Eukaryot. Microbiol. 48: 338-347.

Pernthaler J, Šimek K, Sattler B, Schwarzenbacher A, Bobková J, Psenner R, 1996. Short-term changes of protozoan control on autotrophic picoplankton in an oligo-mesotrophic lake. J. Plankton Res. 18:443-462.

Peštová D, Macek M, Martínez-Pérez ME, 2008. Ciliates and their picophytoplankton-feeding activity in a high altitude warm-monomictic saline lake. Eur. J. Protistol. 44:13-25.

Pirlot S, Vanderheyden J, Descy JP, Servais P, 2005. Abundance and biomass of heterotrophic microorganisms in Lake Tanganyika. Freshwater Biol. 50:1219-1232.

Porter KG, Feig YS, 1980. The use of DAPI for identifying and counting aquatic microflora. Limnol. Oceanogr. 25:943-948.

Psenner R, Schlott-Idl K, 1985. Trophic relationships between bacteria and protozoa in the hypolimnion of a meromictic mesotrophic lake. Hydrobiologia 121:111-120.

Sarmento H, 2012. New paradigms in tropical limnology: the importance of the microbial food web. Hydrobiologia 686:1-14.

Sherr EB, Sherr BF, Berman T, Hadas O, 1991. High abundance of picoplankton-ingesting ciliates during late fall in Lake Kinneret, Israel. J. Plankton. Res. 13:789-799.

Šimek K, Bobková J, Macek M, Nedoma J, Psenner R, 1995. Ciliate grazing on picoplankton in a eutrophic reservoir during the summer phytoplankton maximum: a study at the species and community level. Limnol. Oceanogr. 40:1077-1090.

Šimek K, Macek M, Sed'a J, Vyhnálek V, 1990. Possible food chain relationships between bacterioplankton, protozoans and cladocerans in a reservoir. Int. Revue ges. Hydrobiol. 75:583-596.

Skibbe O, 1994. An improved quantitative protargol stain for ciliates and other planktonic protists. Arch. Hydrobiol. 130:339-347.

Sommaruga R, Psenner R, 1993. Nanociliates of the order Prostomatida: their relevance in the microbial food web of a mesotrophic lake. Aquat. Sci. 55:179-187.

Sommer U, Adrian R, de Senerpont Domis L, Elser JJ, Gaedke U, Ibelings B, Jeppesen E, Lürling M, Molinero JC, Mooij WM, van Donk E, Winder M, 2012. Beyond the plankton ecology group (PEG) model: mechanisms driving plankton succession. Annu. Rev. Ecol. Evol. Syst. 43:429-448.

Sonntag B, Posch T, Klammer S, Griebler C, Psenner R, 2002. Protozooplankton in the deep oligotrophic Traunsee (Austria) influenced by discharges of soda and salt industries. Water Air Soil. 2: 211-226.

Straškrabová V, Callieri C, Cruz-Pizarro L, Hartman P, Macek M, Nedoma J, Šimek K, 1999. Investigations on microbial food webs in mountain lakes - aims and methods. In: V. Straškrabová, C. Callieri and J. Fott (eds.), Pelagic food web in mountain lakes. Mountain Lakes Research Program. J. Limnol. 58:77-87.

Tarbe AL, Unrein F, Stenuite S, Pirlot S, Sarmento H, Sinyinza D, Descy JP, 2011. Protist herbivory: a key pathway in the pelagic food web of Lake Tanganyika. Microb. Ecol. 62:314-323.

Tirok K, Gaedke U, 2007. Regulation of planktonic ciliate dynamics and functional composition during spring in Lake Constance. Aquat. Microb. Ecol. 49:87-100.

Triadó-Margarit X, Casamayor EO, 2015. High protists diversity in the plankton of sulfurous lakes and lagoons examined by 18s rRNA gene sequence analyses. Environ. Microbiol. Rep. 7:908-917.

Trigg PI, 1985. Recent advances in malaria parasite cultivation and their application to studies on host-parasite relationships: a review. Bull. World Health. Organ. 63:387-398.

Wagener S, Schulz S, Hanselmann KC, 1990. Abundance and distribution of anaerobic protozoa and their contribution to methane production in Lake Cadagno. FEMS Microbiol. Ecol. 74:39-48.

Weisse T, Müller H, Pinto-Coelho RM, Schweizer A, Springman D, Baldringer G, 1990. Response of the microbial loop to the phytoplankton spring bloom in a large prealpine lake. Limnol. Oceanogr. 35:781-794.

Woelfl S, Geller W, 2002. Chlorella-bearing ciliates dominate in an oligotrophic North Patagonian lake (Lake Pirehueico, Chile): abundance, biomass and symbiotic photosynthesis. Freshwater Biol. 47:231-242.

Yasindi AW, Taylor WD, Lynn DH, 2007. The community composition and biomass of pelagic ciliated protozoa in East African lakes. Afr. J. Aquat. Sci. 32:175-183. 